\title{
The genetic aspect and morphological appearance of achondrogenesis
}

\section{Mauritius Lambertus Edy Parwanto*}

Department of Biology, Faculty of Medicine, University of Trisakti, Jakarta, Indonesia

Received: 21 June 2017

Accepted: 30 June 2017

\section{*Correspondence:}

Dr. Mauritius Lambertus Edy Parwanto,

E-mail: edyparwanto@trisakti.ac.id

Copyright: (c) the author(s), publisher and licensee Medip Academy. This is an open-access article distributed under the terms of the Creative Commons Attribution Non-Commercial License, which permits unrestricted non-commercial use, distribution, and reproduction in any medium, provided the original work is properly cited.

\begin{abstract}
Achondrogenesis (ACG) is a number of disorders that are the most severe form of congenital chondrodysplasia characterized with bones and cartilage malformation. Generally, characteristic of ACG is a small body, short limbs, and other skeletal abnormalities. As a result of infants with ACG their serious health problems, usually born prematurely, are stillborn, or die shortly after birth from respiratory failure. Currently 3 type variants of ACG such as ACG-1A, ACG-1B and ACG-2. ACG-1A appears to be autosomal recessive (AR), with thyroid hormone receptor interactor 11 (TRIP11) gen mutation, while ACG1B also appears to be AR, with diastrophic dysplasia sulfate transporter or DTDST (SLC26A2) gen mutation. ACG-2 is caused by autosomal dominant (AD), with type 2 collagen (COL2A1) gen mutation. ACG-1A had characterizid such as physis abnormal, vertebral bodies with unossified or smal and oval, skull poorly ossified, periodic acid-Schiff (PAS) stain positive chondrocyte inclusions finding in long bones. ACG-1B had physis abnormal, vertebral bodies with unossified or smal and oval, skull ossified, perichondrocyte collagen rings finding in long bones. ACG-2 also had physis abnormal, metaphyseal cupping, vertebral bodies with unossified or small and oval, enlarged chondrocyte lacunae.
\end{abstract}

Keywords: Achondrogenesis, COL2A1, Gen mutation Physis abnormal, SLC26A2, TRIP11

\section{INTRODUCTION}

Achondrogenesis (ACG) is a number of disorders that are the most severe form of congenital chondrodysplasia (malformation of bones and cartilage). These conditions are characterized by a small body, short limbs, and other skeletal abnormalities. As a result of their serious health problems, infants with ACG are usually born prematurely, are stillborn, or die shortly after birth from respiratory failure. Some infants, however, have lived for a while with intensive medical support. ${ }^{1}$

The other characteristic of ACG is a lethal form of congenital dystrophy characterised by micromelia macrocephaly and a short trunk that involves both proximal and distal extremity segments. ${ }^{2,3}$
Based on radiologic and histopathologic appearance, generally there are 3 variants of ACG, namely ACG type $1 \mathrm{~A}$ (Houston-Harris type), ACG type 1B (ParentiFraccaro type $=$ Fraccaro type), and ACG type 2 (LangerSaldino type). ACG type 1A (ACG-1A) with apparently normal cartilage matrix but inclusions in chondrocytes, ACG type 1B (ACG-1B) with abnormal cartilage matrix. ${ }^{4}$ These findings were confirmed by another group shortly thereafter. ${ }^{5}$ Some cases have been published previously and diagnosed as ACG-1B, and the other cases was diagnosed as ACG-1A, while Parenti case this may be classified as ACG type 2 (ACG-2). ${ }^{4,6-9}$ ACG-1A caused by mutation of thyroid hormone receptor interactor 11 (Trip11) gen. ${ }^{10}$ Inheritance pattern of ACG-1A appears autosomal recessive (AR). ${ }^{10,11}$ ACG-1B caused by mutation of the diastrophic dysplasia sulfate transporter 
gene (SLC26A2). Inheritance pattern of ACG-1B appears AR. ACG type 2 (ACG-2) caused by mutation of the type 2 collagen gene (COL2A1). Inheritance pattern of ACG-2 appears autosomal dominant (AD). ${ }^{11}$ In 1983, a new classification of ACG was classified into 4 type and adopted in the McKusick catalogue. ${ }^{12,13}$

Not just the morphological appearance of ACG caused by genetic factors. In the other cases revealed that morphological appearance among others determined by body mass index (BMI). According to state that BMI is determined by genetic and environmental factors. ${ }^{14}$ More over, one of the genetic factors that determine the BMI is a genetic polymorphism of sex hormone binding globulin (SHBG), whereas the intake of nutrients is one of the environmental factors. In detail, that differences of dietary intake at mother in childbearing age with BMI $<18.5 \mathrm{~kg} / \mathrm{m}^{2}$ and has heterozygous variant SHBG genotype $(\mathrm{W} / \mathrm{v})$ determine to status of chronic energy deficiency (CED), therefore that low protein, fat and carbohydrate intake then getting low of CED status. ${ }^{15} \mathrm{We}$ suspect that beside of genetic factor, environment factor such as dietary intake also affected to ACG. Because that too need of ACG reports from genetic aspect and dietary intake.

\section{The genetically of achondrogenesis}

ACG-1A had mutation of Trip11 gen. The Trip 11 gen encodes the Golgi microtubule-associated protein 210 (GMAP-210). The biochemical data provide strong evidence that GMAP-210 is a Golgi-associated protein that directly interacts with microtubule ends. ${ }^{16}$ The mutation of Trip 11 gen caused loss-of-function GMAP210. GMAP-210 moves proteins from the endoplasmic reticulum to the Golgi apparatus. ${ }^{1}$ More over that mice lacking GMAP-210 die at birth with a pleiotropic phenotype that includes growth restriction, ventricular septal defects of the heart, omphalocele, and lung hypoplasia. ${ }^{17}$

The Golgi apparatus is an organelle with multiple complex functions. The Golgi complex is involved in cellular processes other than the classical trafficking and biosynthetic pathways. These organel can be considered as a cellular headquarters where cargo sorting/processing, basic metabolism, signalling and cell fate decisional processes converge. ${ }^{18}$ Because the defect of GMAP-210, thus this protein is not able to move from endoplasmic reticulum to Golgi apparatus, and they remain in the endoplasmic reticulum, which swells up. The circumstances led to disruption of skeletal formation process, so that the fetus has an abnormal phenotype. More over, the TRIP11 gene analyzed in 10 unrelated patients with ACG-1A. For all patients was done to identified of homozygous or compound heterozygous loss-of-function mutations. The result of analysis showwed that two mutations (c.202-2A $\rightarrow \mathrm{G}$ and c.589$2 \mathrm{~A} \rightarrow \mathrm{G})$ affect intronic splice-acceptor sites and five mutations (p.R264X, p.R1028X, p.Q1160X, p.R1167X, and p.W1224X) are nonsense mutations. ${ }^{1}$

ACG 1B caused by mutations in SLC26A2 (diastrophic dysplasia sulfate transporter or DTDST) gene. The SLC26A2 gen located on 5q, hereditary by autosome recessif (AR). ${ }^{13}$ The gen of SLC26A2 which encodes a sulfate transporter. ${ }^{1}$ More over, mutated alleles of the SLC26A2 gene cause each of the four recessive chondrodysplasias, ie: diastrophic dysplasia (DTD), multiple epiphyseal dysplasia (MED), atelosteogenesis Type II (AO2), and ACG-1B. Result of study showed that SLC26A2 mRNA and protein immunostaining were detected in developing fetal hyaline cartilage. More over, SLC26A2 expression is also detected in tissues not affected in chondrodysplasias caused by SLC26A2 mutations. ${ }^{19}$

ACG-2 is characterized genetically by a mutation in the COL2A1 gene. The COL2A1 gen located on chromosome 12. Hereditary of ACG-2 by autosome dominant (AD). ${ }^{13}$ The COL2A1 gene involved in the production of type 2 collagen, which is essential for hyaline cartilage formation and endochondral ossification. The mutation of COL2A1 gen affects type 2 procollagen formation, disrupting formation of the triple helix conformation necessary for proper function. Because that decreased type 2 collagen secretion and abnormal intracellular retention of the defective protein. ${ }^{20}$ The other cases showed that overmodified type 2 collagen and the presence of type 1 collagen was found in the cartilage matrix of all seven cases. Five patients were heterozygous for a nucleotide change that predicted a glycine substitution in the triple helical domain (G313S, G517V, G571A, G910C, G943S). Analysis of cartilage type 2 collagen in all five cases suggested incorporation of the abnormal $\alpha 1$ (II) chain in the extracellular collagen trimers. The G943S mutation has been reported previously in another unrelated patient with a strikingly similar phenotype, illustrating the possible specific effect of the mutation. ${ }^{21}$ More over also reported that histologic sections of the epiphyses show a markedly disordered physis with advanced periosteal ossification. Besides that, corresponding to radiologic metaphyseal cupping, deficient chondroid matrix, markedly enlarged chondrocyte lacunae, and increased cartilage vascularity with perivascular fibrosis. . $2,23^{2}$

\section{Morphological appearance of achondrogenesis type 1}

The first cases of ACG-1 was detected by prenatal ultrasonography (USG) at 20 weeks gestation. The USG showed single live intrauterine with gross skeletal dysplasia-ACG-1. On USG there was absence of forearm bones in both upper limbs and absence of bones in the right lower limb. A dwarfed fetus with large head, short neck and chest and short limbs was terminated transvaginally. Radiologic examination revealed appearance of ACG-1. Though the case had no known risk factor and the phenotypic abnormality was mild, modern 
development in prenatal screening made the early detection possible. The other data in this case showed that a detailed family history of the patient and her husband should be elicited along with clinical, genetic, radiographic and morphological examination. ACG-1 from India presented in Figure 1.
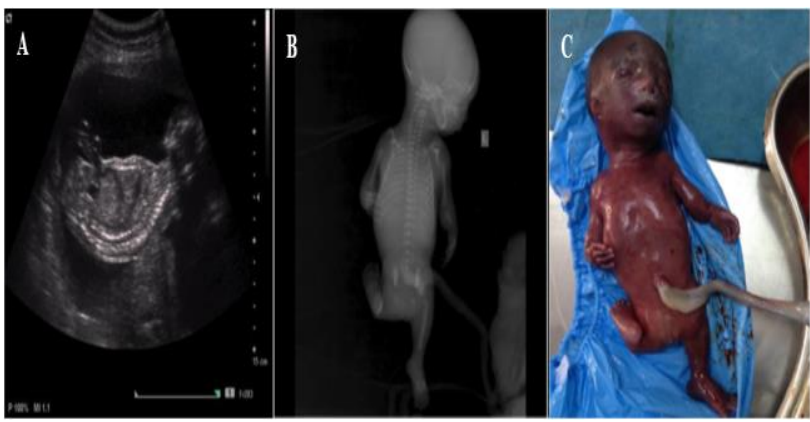

ACG-1=A. Fetus viewed by ultrasonography. B. The radiograph of fetus. C. The photograph of fetus postmortem neonatal.

Figure 1. Achondrogenesis type 1 from India.

The second cases of ACG-1 reported that 32-year-old Turkish woman, gravida 3, para 2. Her patient diagnoses of gestational diabetes mellitus, polyhydramnios, and abnormal results of an ultrasound examination performed by obstetrician. First degree consanguinity was noted between the couple. Her first pregnancy had ended in a cesarean section at 33 weeks' gestation with a diagnosis of severe preeclampsia and breech presentation. Although it had not been possible to make an exact diagnosis, the appearance of the male baby had suggested dwarfism.

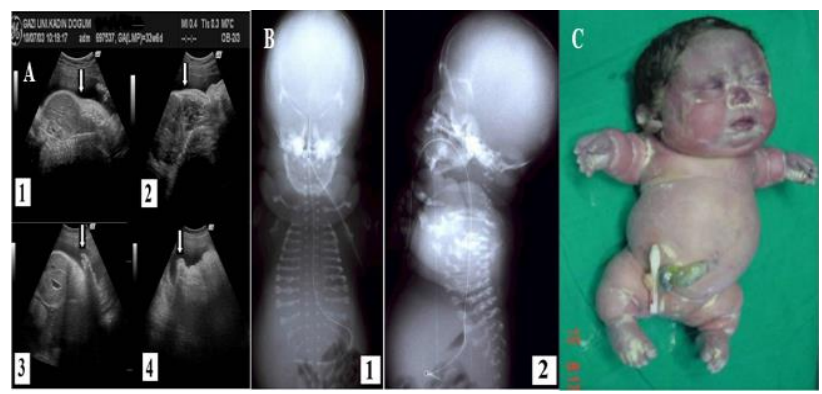

A. The sonograms of prenatal fetus at 33 weeks and 6 days of gestation. A.1. High abdomen/thorax ratio. A.2. Pulmonary hypoplasia and narrow thorax. A.3 and A.4. extreme micromelia. B. The radiograph of post mortem whole body. B.1. Postmortem anteroposterior position of the baby. B.2. Postmortem lateral position of the baby. C. The appearance of the baby after birth.

\section{Figure 2: Achondrogenesis type 1 from Turkies} women.

The baby had died within 3 hours of birth. Her second pregnancy had been complicated by polyhydramnios, preeclampsia, and gestational diabetes mellitus and had ended in the birth of a healthy male baby. The 3th pregnancies was terminated by cesarean section at 34 weeks and 4 days. ${ }^{24}$ Prenatal sonograms examination and characteristic of the fetus ACG-1 from Turkish women presented at Table 1. Female baby died was diagnosed with ACG-1 from Turkish women presented at Figure 2.

Table 1: Prenatal sonograms examination and characteristic of the fetus achondrogenesis type 1 from Turkish women.

\begin{tabular}{|ll|}
\hline $\begin{array}{l}\text { Prenatal sonograms examination } \\
\text { and } 4 \text { days }\end{array}$ & $\begin{array}{l}\text { Characteristis of the fetus was terminated by cesarean section at } 34 \text { weeks } \\
\text { and }\end{array}$ \\
$\begin{array}{ll}\text { Micromelia, narrow thorax, high } & \text { - Female baby died within the first thirty minutes of birth. } \\
\text { hydomen/thorax ratio, pulmonary } & \text { - Birth body weight } 1810 \text { gram and } 31 \text { centimeters. } \\
\text { hypoplasia, and poor } & \text { - Hydrops, severe tetramicromelia, and a flat face. } \\
\text { mineralization of the skull and } & \text { - The head was disproportionately large relative to the reduced neck, trunk and } \\
\text { vertebrae. } & \text { limb length. } \\
\text { - Polyhydramnios and a } & \text { Anteroposterior and lateral postmortem whole-body radiographs revealed } \\
\text { pseudohydropic appearance, } & \text { inadequate ossification of the bones, except for the clavicles, and there were } \\
\text { pleural and pericardial effusion, } & \text { short beaded ribs with multi-ple fractures, minimal ossification of vertebral } \\
\text { and low-lying ears } & \text { bodies, arched iliac wings, stellate femurs and humeri, and micromelic long } \\
& \text { bones. }\end{array}$ \\
\hline
\end{tabular}

\section{Achondrogenesis type $1 A$}

ACG-1A derived from Turkey, pregnant women gravida 2 , parity 1 , consult regularly to Obstetricians. The examination was conducted using ultrasonography at week 16 of the last menstrual period. The examination results indicate that the presence of skeletal dysplasia. No characteristics in a personal or family history. Laboratory results were in the normal range. Using the ultrasonography shows a single living fetus consistent with the $17^{\text {th }}$ gestational week in terms of head circumference, biparietal diameter and abdomen circumference and with the $12^{\text {th }}$ gestational week in terms of femur length. During the examination by USG, the case was established to have distinct retardation in all long bones when compared to those of the same 
gestational age in addition to macrocephaly, narrow thorax, protuberant abdomen, reduced thorax/abdomen ratio, reduced vertebral echogenicities, horizontally placed short ribs with irregular cortex and increased echogenicity, pyelectasis, protruding forehead, nasal bone hypoplasia, increased skin thickness, and polyhydramnios.
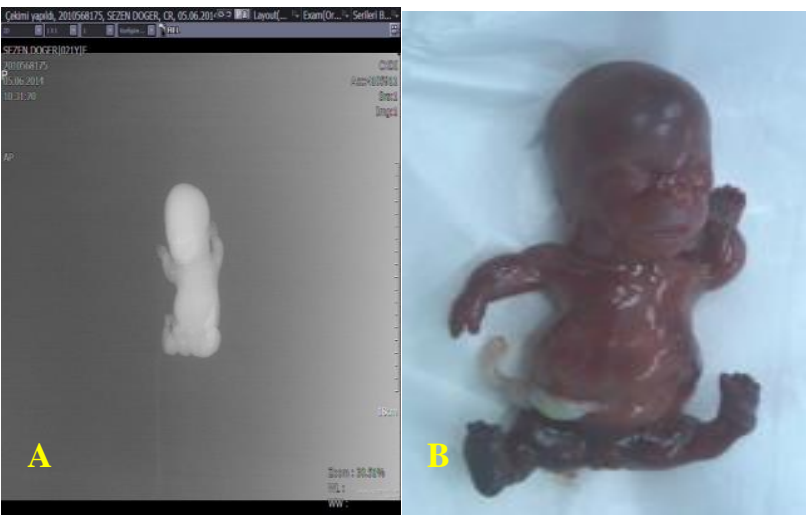

A. The radiograph of the fetus. The fetus shows shortness of extremities and reduced ossification in calvarium and vertebrae. B. Post-termination photograph of the fetus. The long bones of all extremities appear to be short, and macrocephaly, flat nasal root, protruding forehead, low-set ears and narrow thorax are prominent.

Figure 3: The photograph and radiograph of achondrogenesis type $1 \mathrm{~A}$ from Turkey.

The result of amniosynthesis shows that kariotype $46 \mathrm{XX}$ and normal. After genetic counselling, then it is advisable for the termination of the pregnancy. Pregnancy was terminated after obtaining the consent given by the family. Post-mortem examination revealed severe micromelia, narrow thorax, abdomen wide, protruding forehead, flat nasal root, hypertelorism, and low-set ears in the fetus. They Showed almost non-existent ossification in the vertebrae and loss of mineralization in the calvarium, as well as distinct shortness of the extremities. Base on the result of clinical and radiological evaluations, the fetus was diagnosed as ACG- $1 \mathrm{~A} .{ }^{25}$ The photograph and radiograph results of ACG-1A from Turkey presented in Figure 3.

The other cases of ACG-1A was reported that human fetus at 27-weeks-old with reveals a lack of mineralization in the skull and the vertebral column and short limbs (Figure 4). The other cases reported that patient of ACG-1A showed swollen endoplasmic reticulum and vesicular Golgi apparatus. This appearance corresponds to the absence of vertebral-body and skull ossification on radiography, the lack of organized columnar zones of proliferating chondrocytes on histologic analysis. The reduced expression of CollOal on immunohistochemical analysis, and the expanded endoplasmic reticulum cisternae in chondrocytes on electron microscopy have all been reported in affected patients. ${ }^{8,26}$

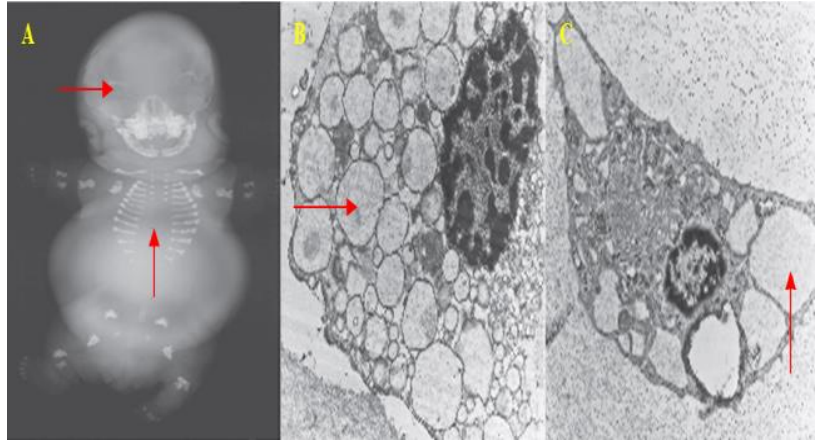

A. The radiograph of human fetus with reveals a lack of mineralization in the skull and the vertebral column (red arrows) and short limbs. B, C. The electron micrographs show chondrocytes from two unrelated fetuses with ACG-1A, with swollen endoplasmic reticulum (red arrows) and vesicular Golgi apparatus (arrowhead in upper image).

Figure 4: Achondrogenesis type 1A of fetus showed at 27-weeks-old.

\section{Achondrogenesis type $1 B$}

Superti-Furga reported the cases of ACG-1B with characterized in a breech position. ${ }^{13}$ The fetus after birth is regarded as abnormal. Fetuses show disproportion between the head, seen approaching a normal or normal size, and the rest of the body, so looked short of normal. The other appearance of fetus ie: flat face, short neck, and the neck has a soft tissue may be thickened, narrow thorax with protuberant abdoment. The fetus newborns appear fat or hydropic, this is due to the amount of soft tissue relative to the short skeleton. Often suffer of hernia inguinal or umbilical.
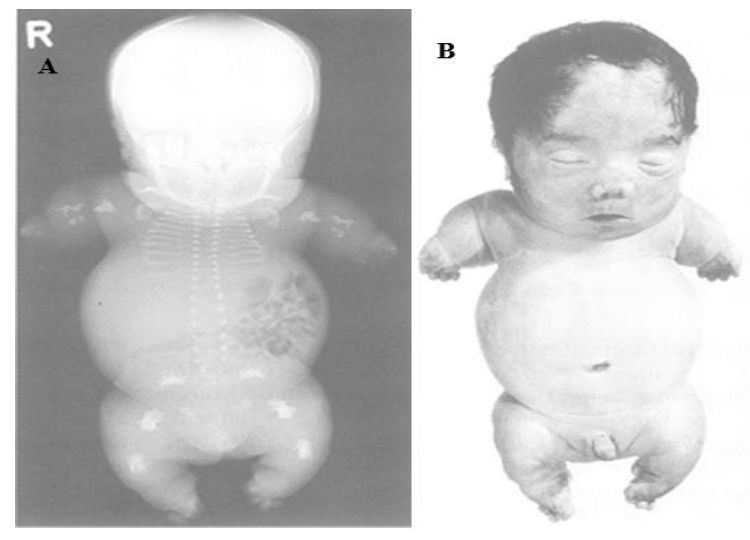

Figure 5: The result of $X$ ray and clinical appearance of fetus with achondrogenesis type $1 \mathrm{~B}$. A. The radiograph of fetus. $B$. Clinical appearance of fetus.

The newborn fetal body is severely shortened, sometimes resembling flippers, sometimes, when an articular crease at the hip or shoulder is present, resembling sausages. The severe micromelia with short stubby fingers. The feet and toes are rotated inwards in a fashion reminiscent of diastrophic dysplasia. The external organs appeared unremarkable. Fetuses with ACG have short femora. 
Display short femur seen during an ultrasound during pregnancy. The use of USG also visible nuchal edema, reduce the length of the buttocks, poor ossification of the vertebral body and leg bones (leading to difficulty in determining reviews in length), and polyhydramnios. Fetus with ACG-1B born at 34 weeks and died 25 minutes after birth. ${ }^{13}$ The view of $\mathrm{X}$ ray and clinical appearance of ACG-1B presented at Figure 5.

\section{Clinical appearance of achondrogenesis type 2}

Female human fetus was delivered transvaginally at 22 weeks gestation and died shortly after birth. Until 20 weeks of gestation showed uneventful, when an USG examination showed that the fetus significantly shortened femur for the gestational age and nuchal edema.

Table 2: The characteristic of morphological appearance, radiological and histological examination of fetus was diagnosis achondrogenesis type 2.

\begin{tabular}{|c|c|c|}
\hline $\begin{array}{l}\text { Morphological } \\
\text { appearance }\end{array}$ & Radiological & Histological \\
\hline $\begin{array}{l}\text {-Fetus body- } \\
\text { weight: } 490 \text { grams. } \\
\text {-Body lenght of } \\
17.3 \mathrm{~cm} \\
\text {-She had a } \\
\text { craniofacial } \\
\text { anomaly ie } \\
\text { relatively large } \\
\text { calvarium. The size } \\
\text { of the head } \\
\text { circumference ie } \\
22.3 \text { cm and } \\
\text { biparietal diameter } \\
\text { ie } 06.15 \text { cm. } \\
\text {-Micrognathia, } \\
\text { small mouth, } \\
\text { tongue } \\
\text { hypertrophy, flat } \\
\text { nose and } \\
\text { hypertelorism. } \\
\text {-The neck of the } \\
\text { fetus is very short, } \\
\text { so short chest with } \\
\text { antero-posterior } \\
\text { flattening. } \\
\text {-The abdomen was } \\
\text { large and } \\
\text { distended. There } \\
\text { was severe } \\
\text { shortness of upper } \\
\text { and lower limbs, } \\
\text { especially from } \\
\text { rhizomelic } \\
\text { segment. } \\
\text {-Extremities are } \\
\text { also bent and } \\
\text { bilateral club foot. }\end{array}$ & $\begin{array}{l}\text {-Shortness of } \\
\text { limbs. The } \\
\text { tubular bones } \\
\text { were short and } \\
\text { broad. The } \\
\text { metaphyses of } \\
\text { tubular bones } \\
\text { were widened } \\
\text { with irregular } \\
\text { ends and lateral } \\
\text { spurs. } \\
\text {-The calvaria } \\
\text { were relatively } \\
\text { well ossified. } \\
\text {-The vertebral } \\
\text { bodies were } \\
\text { insufficiently } \\
\text { ossified, } \\
\text { predominantly } \\
\text { in the cervical } \\
\text { spine. } \\
\text {-The ribs were } \\
\text { horizontal } \\
\text { without } \\
\text { fracture. } \\
\text {-The iliac } \\
\text { wings were } \\
\text { square with a } \\
\text { horizontal } \\
\text { acetabular } \\
\text { angle and a } \\
\text { concave } \\
\text { internal edge. } \\
\text {-The ischial } \\
\text { and pubic } \\
\text { bones were } \\
\text { nonossified. }\end{array}$ & $\begin{array}{l}\text {-Chondroosseous } \\
\text { tissues showed } \\
\text { hypervascularity } \\
\text { of cartilage. } \\
\text { Moreover, } \\
\text { cellular density } \\
\text { was high and the } \\
\text { matrix was } \\
\text { reduced. } \\
\text {-The cells were } \\
\text { large, often } \\
\text { starred, and their } \\
\text { lacunae were } \\
\text { enlarged. } \\
\text {-In the growth } \\
\text { zone, the cells } \\
\text { showed irregular } \\
\text { columns. } \\
\text { Moreover, this } \\
\text { cell ended in } \\
\text { hypertrophic } \\
\text { cells placed } \\
\text { irregularly. } \\
\text {-Vascular } \\
\text { penetration was } \\
\text { irregular in the } \\
\text { ossification line. } \\
\text { The primary } \\
\text { trabeculae were } \\
\text { thickened, } \\
\text { irregular and } \\
\text { uneven. }\end{array}$ \\
\hline
\end{tabular}

The fetus was conceived by a 26-year-old mother, while her husband was 30 years old. In the family can not be found ACG history and are not known exposure of the teratogens. The results of amniocentesis showed that the baby is female and has a normal karyotype.

Based on examination of organs revealed that the growth and development of gestational age there are no significant anomalies. On the basis of clinical findings, radiological and microscopic, this case was diagnosed as a mild form of ACG-2 (Langer-Saldino). ${ }^{27}$ The characteristic of morphological appearance, radiologic and histologic examination of fetus was diagnosis ACG-2 presented in Table 2 .

The examination by ultrasonography, radiography, photography and microscopy of the fetus of ACG-2 presented in Figure 6.

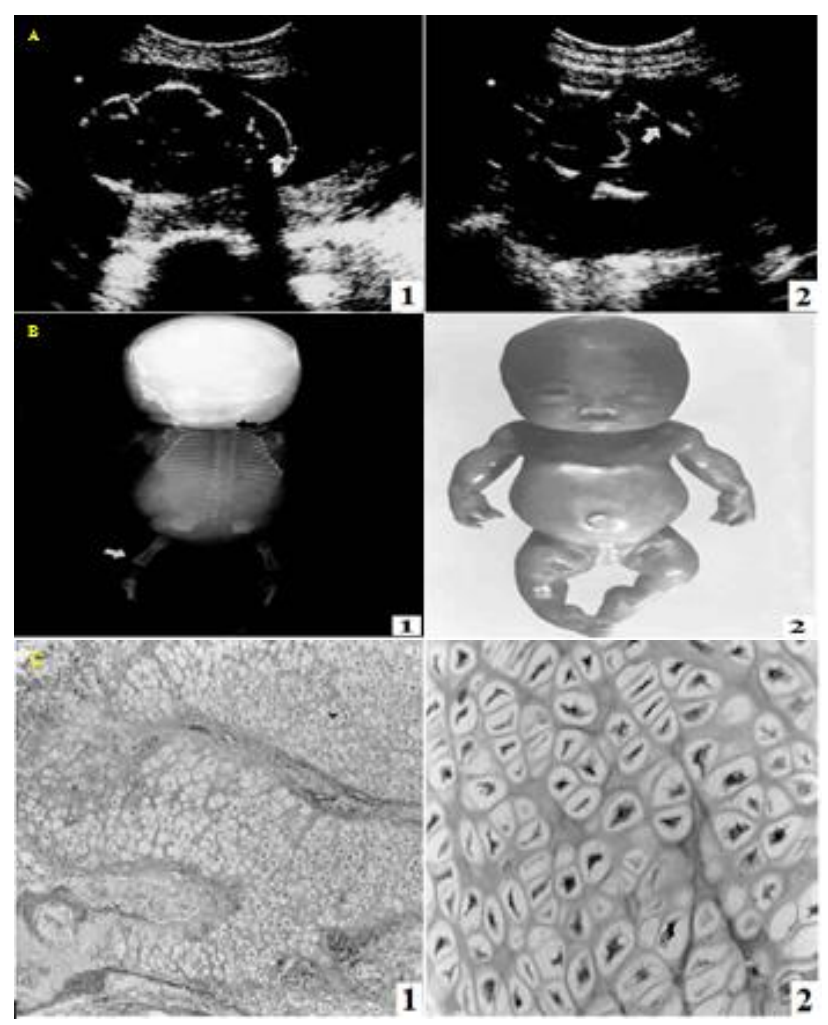

A. The fetus ultrasonograph at 22-weeks gestation. A.1. nuchal edema. A.2. Femur (shortened). Observed femur length/expected femur length $2.31 / 3.2=0.72$ ). B. The radiograph and photograph of fetus post mortem. B.1. The radiograph of fetus at postmortem examination shows short tubular bone, widened metaphyses and non-ossified cervical vertebrae. B.2. The photograph of fetus at postmortem examination shows craniofacial anomaly, short neck and chest, distended abdomen and severe micromelia. C. Light microscopy examination of costochondral junction with hematoxylin and eosin staining (x 100). C.1. The higher cellularity and reduced matrix. C.2. The cells and their lacunae are enlarged.

Figure 6: Examination by ultrasonography, radiography, photography and microscopy of the fetus of achondrogenesis type 2 . 


\section{Achondrogenesis type 2 at the couple had a fourth pregnancy}

A familial case of ACG-2 caused by COL2A1 gen mutation and 'patchy' expression in the mosaic father was reported. The case of ACG-2 occurred on nonconsanguineous young couple had four pregnancies of an apparently healthy. The first child was born at 32 weeks and died neonatally. In the second pregnancy at 17 weeks gestation showed that short limbs and fetal hygroma in USG examination. Similar findings were observed in the third fetus. These couple had a fourth pregnancy showed findings consistent with ACG-2. ${ }^{28}$

The characteristic of ACG-2 at the couple had a fourth pregnancy presented at Table 3 . The result of examination by USG for fourth fetus with ACG-2 at the couple had a fourth pregnancy presented at Figure 7. The other cases of ACG-2-hypochondrogenesis and severe spondyloepiphyseal dysplasia congenita (SEDC) are lethal forms of dwarfism caused by dominant mutations in type 2 collagen gen (COL2A1). In these cases, reported that 7 patients had mutation of COL2A1 gen. For all 7 patients, 2 patients were male and 5 females. This happens because that ACG-2 are autosomal dominant. The sevent patient had body length varies ranging from $29 \mathrm{~cm}$ to $39 \mathrm{~cm}$ on gestational age between 35-42 weeks, short limbs dan small thorax. Two of 7 patients had cleft palate, 6 of 7 patients had respiratory insufficiency at birth. Age of death varies from 6 hours to 1 year 1 month.

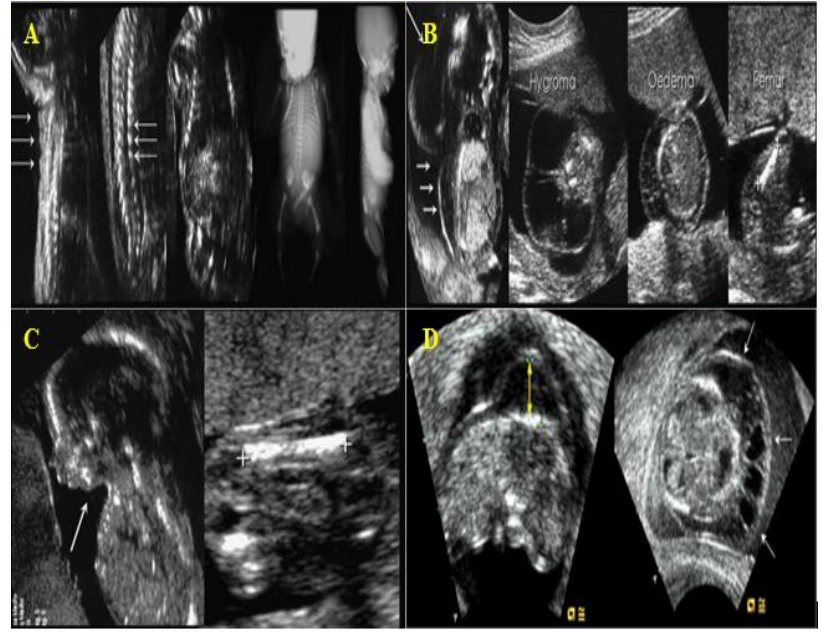

A. The result of ultrasound scan and postnatal radiographs of fetus. Redundant skin (arrows on the left), platispondily (arrows on the right), bell-shaped thorax, wide femural and homeral metaphises. B. The result of ultrasound scan of fetus and showed large and septated nuchal cystic hygroma (arrows; longitudinal and axial scans) and short femur. C. The result of ultrasound scan of fetus and showed micrognathia (arrow) and short femur. D. The result of ultrasound transvaginal scan of fetus and showed increased nuchal translucency (left, longitudinal scan) and septated nuchal cystic hygroma (right, axial scan).

Figure 7: The result of examination by USG for fourth fetus with achondrogenesis type 2 at the couple had a fourth pregnancy.

Table 3: The characteristic of achondrogenesis type 2 at the couple had a fourth pregnancy.

\begin{tabular}{|c|c|c|c|}
\hline The first pregnancy & $\begin{array}{l}\text { The second } \\
\text { preganancy }\end{array}$ & The third pregnancy & $\begin{array}{l}\text { urt } \\
\text { incy }\end{array}$ \\
\hline $\begin{array}{l}\text {-Maternal age } 30 \text { years. } \\
\text {-Evaluated at } 28 \text { weeks and } 5 \text { days for } \\
\text { suspected abnormal development of fetal } \\
\text { limbs and mild polyhydramnios. } \\
\text {-Examination at } 28 \text { weeks with USG } \\
\text { showed a viable fetus was recognized with } \\
\text { circumferences of the head and abdomen } \\
\text { appropriate for gestational age. All long } \\
\text { bones showed that the limb shortening } \\
\text { involved all segments. The other anomali as: } \\
\text { micrognathia, fetal skin redundance in the } \\
\text { neck and thorax region, and a 'bell-shaped' } \\
\text { thorax. The spine had an ovoid shape and } \\
\text { flattening of vertebral bodies. } \\
\text {-The pregnancy ended with preterm labor at } \\
32 \text {-week gestation. Weight of fetus a } 1.700 \\
\text { gram, male and died in the newborn period. } \\
\text { There was a short, thick neck, flat face with } \\
\text { a deep nasal bridge, micrognathia, and short } \\
\text { limbs. }\end{array}$ & $\begin{array}{l}\text {-Maternal age } 32- \\
\text { years. } \\
\text {-Evaluated at } 16 \\
\text { weeks of pregnancy } \\
\text { for fetal karyotyping } \\
\text { as } 46, \text { XX. At USG, } \\
\text { the fetus showed a } \\
\text { large and septated } \\
\text { nuchal cystic } \\
\text { hygroma associated } \\
\text { with hydrops and } \\
\text { hyperechoic bowel. } \\
\text {-Fetal biometry of } \\
\text { the head was } \\
\text { appropriate for } \\
\text { gestational age. } \\
\text {-Micromelia. } \\
\text {-The pregnancy was } \\
\text { terminated at } 17 \\
\text { weeks gestation. }\end{array}$ & $\begin{array}{l}\text {-Maternal age } 33 \text { years. } \\
\text {-Evaluated for fetal } \\
\text { karyotyping at } 17+3 / 7 \\
\text { weeks. } \\
\text {-The circumferences of the } \\
\text { head and abdomen were } \\
\text { appropriate for gestational age. } \\
\text {-All long bones showed that } \\
\text { only the proximal segments } \\
\text { were shortened. } \\
\text {-Micrognathia. } \\
\text {-The pregnancy was } \\
\text { terminated at } 18 \text { weeks } \\
\text { gestation. } \\
\text {-Postmortem examination } \\
\text { showed a female fetus affected } \\
\text { by a marked rhizomelic } \\
\text { shortening of limbs. There was } \\
\text { a prominent forehead, frontal } \\
\text { bossing, and depressed nasal } \\
\text { bridge. }\end{array}$ & $\begin{array}{l}\text {-Screened at } 10.6 \\
\text { weeks for prenatal } \\
\text { diagnosis by } \\
\text { chorionic villus } \\
\text { sampling. } \\
\text {-Transvaginal USG } \\
\text { showed a septated } \\
\text { nuchal cystic } \\
\text { hygroma with } \\
\text { enlarged jugular } \\
\text { lymphatic sacs, } \\
\text { generalized fetal } \\
\text { hydrops developed } 1 \\
\text { week later. Amniotic } \\
\text { fluid, fetal biometry } \\
\text { and heart rate were } \\
\text { normal. } \\
\text {-The pregnancy was } \\
\text { terminated at } 11 \\
\text { weeks gestation. }\end{array}$ \\
\hline
\end{tabular}

Abbreviations: USG = ultrasonography. 
Resting cartilage with mild to very hypervascular and slightly increased vascular canals. Chondrocytes with inclusion bodies and 4 of 7 patients showed dilated rough endoplasmic reticulum. Six of 7 pasien with abnormal growth palate. ${ }^{21}$ The radiographs of patients ACG-2 and severe spondyloepiphyseal dysplasia congenita presented in Figure 8.

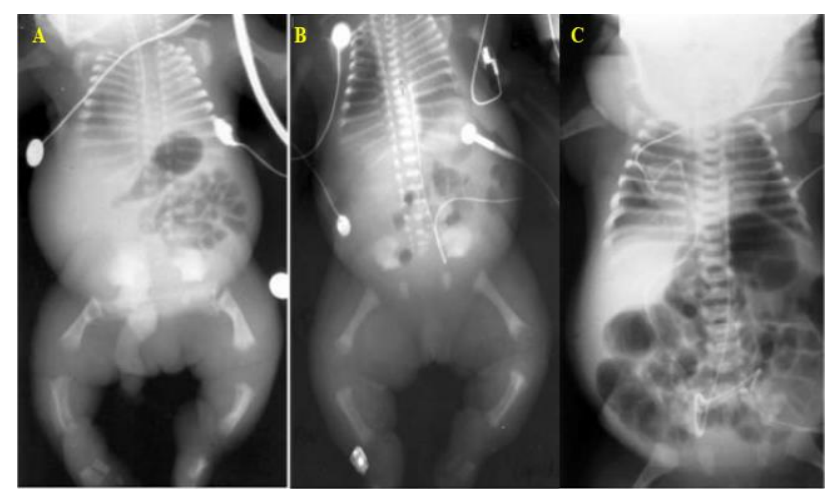

A. Patient R86-153 represents a severe phenotype characterised by short tubular bones with metaphyseal irregularities, minimal ossification of vertebral bodies in the thoracic spine, hypoplastic iliac wings with flat acetabular roofs, and short ribs. B. Patient R8332 shows an intermediate phenotype. C. Patient R91-68 illustrates a milder phenotype with normal metaphysis of shortened tubular bones, flattened but normally ossified vertebral bodies, normal acetabular roofs, and a less narrow chest.

Figure 8: The radiographs of patients with achondrogenesis type 2 and severe spondyloepiphyseal dysplasia congenita.

\section{Achondrogenesis type 2 in a fragmented fetus}

The cases of ACG-2 in a fragmented fetus was reported. These cases experienced by mother of age 29 years, gravida 2 para 1 with a history of gestational diabetes, asthma, smoking, and prior cesarean section.

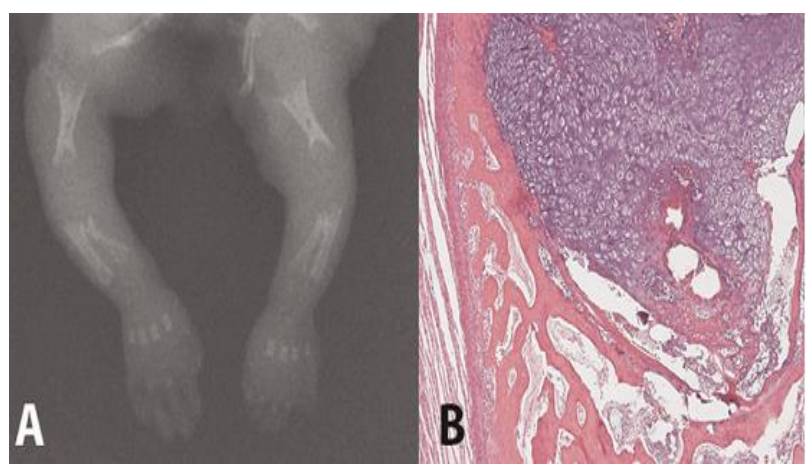

A. The radiographs of the upper extremities show markedly shortened limbs and long bones. The metaphyseal ends, especially of the distal humerus, show prominent metaphyseal cupping, a feature seen in ACG-2. B. The histology of the long bone metaphyses shows disorganized endochondral ossification and ballooning chondrocytes.

Figure 9: The radiographs and histology of the long bone in achondrogenesis type 2 .
There was no relevant family history. Elective termination by dilation and evacuation (D and E) was performed at a $154 / 7$ weeks. ${ }^{10}$ Prenatal, post mortem, radiography and histology examination of fragmented fetus in ACG-2 presented in Table 4. The radiographs and histology of the long bone in ACG-2 presented in Figure 9. The photograph, radiograph and histology examination of vertebral column in ACG-2 presented in Figure 10.

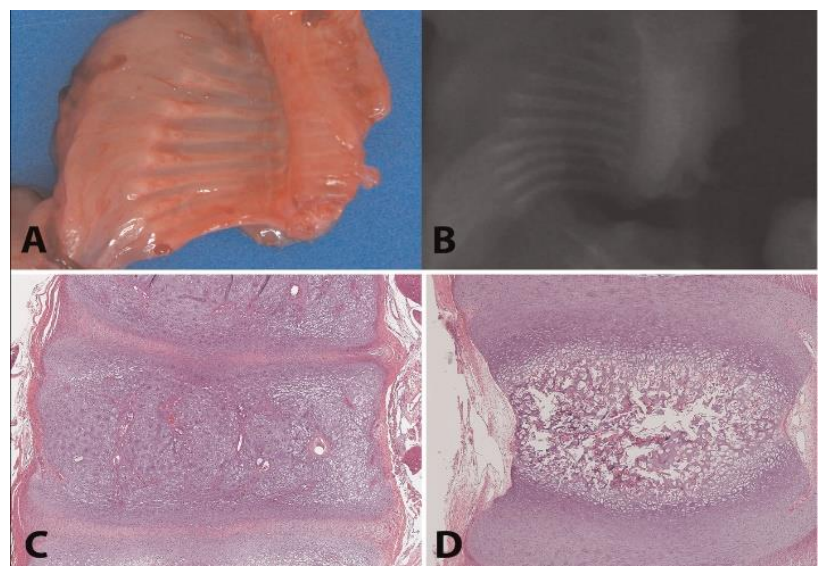

A. The photograph of the fragmented vertebral column. B. The tissue radiograph of the fragmented vertebral column. In this figure showed that the lack of ossification of the vertebral bodies and no rib fractures. C, D. Histology examination to confirms of the lack of vertebral body ossification.

Figure 10: The photograph, radiograph and histology examination of vertebral column in achondrogenesis type 2 .

According to Hansen et al, the size toe-heel length 1.4 $\mathrm{cm}$ is small for 13-14 weeks of pregnancy. ${ }^{29}$ Based on the expected value by Elejalde and de Elejalde that the length of femora 12.5 to $27 \mathrm{~mm}$, and humeri 12.5 to $26 \mathrm{~mm}$, thus the length of femora $6 \mathrm{~mm}$, whereas the humeri 7 $\mathrm{mm}$ in fragmented fetus was shorten. ${ }^{30}$

Based on the findings of morphological observation, radiological, histological and genetic analysis, the fetus is fragmented concluded experiencing ACG-2. Moreover, revealed that the fetus showed heterozygous mutation in the COL2A1 gene [c.1358G>A transition (Gly453Asp) in exon $19 .{ }^{10}$

Superti-Furga et al to state that a distinction between ACG-1A, 1B ACG, and ACG-2 on clinical grounds is difficult. ${ }^{13}$

More details that almost normal hands are seen in ACG2, whereas in ACG-1A and ACG-1B showed that the hands are evidently shortened. While the radiological observation showed that rib fractures, thus may suggest as ACG-1A. Guidelines for the diagnostic of ACG presented in Table 5. 
Table 4: Prenatal, post mortem, radiography and histology examination of fragmented fetus in achondrogenesis type 2.

\begin{tabular}{|c|c|c|c|}
\hline $\begin{array}{l}\text { Prenatal } \\
\text { examination }\end{array}$ & Post mortem examination & $\begin{array}{l}\text { Photography and } \\
\text { radiography } \\
\text { examination }\end{array}$ & Histology examination \\
\hline $\begin{array}{l}\text {-USG revealed } \\
\text { a cystic } \\
\text { hygroma, } \\
\text { possible facial } \\
\text { clefting, an } \\
\text { abnormal 4- } \\
\text { chamber heart, } \\
\text { a small chest, } \\
\text { upper limb } \\
\text { shortening, and } \\
\text { an unspecified } \\
\text { lower limb } \\
\text { deformity. } \\
\text { - Cytogenetic } \\
\text { analysis shows } \\
\text { that female } \\
\text { fetus has a } \\
\text { normal } \\
\text { karyotype (46, } \\
\text { XX). }\end{array}$ & $\begin{array}{l}\text {-Toe-heel length } 1.4 \mathrm{~cm} \text {. } \\
\text {-Disruption seen on the head and skull bones, thus } \\
\text { preventing the determination of the head } \\
\text { circumference. The right eye seemed distracted, as } \\
\text { well as the left ear appeared posteriorly rotated. } \\
\text {-Disrupted showed to the spinal column, thoracic } \\
\text { cavity, diaphragm, pericardial cavity and abdominal } \\
\text { cavity, and some of the organs were not identified } \\
\text { among themany loose fragments. } \\
\text {-Partially disrupted also showed on the liver, } \\
\text { pancreas, heart, and intestines. The placenta was } \\
\text { fragmented. } \\
\text {-Disrupted partially also showed on extremities, } \\
\text { more over for all } 4 \text { extremities were markedly } \\
\text { shortened. The right hand was intact and showed } \\
\text { mild clinodactyly of the 5th finger but no } \\
\text { polydactyly or syndactyly. On the other hand, the } \\
\text { left hand was partially disrupted. } \\
\text {-The internal genitalia were disrupted, and the } \\
\text { external genitalia were female. The anus could not } \\
\text { be identified. }\end{array}$ & $\begin{array}{l}\text { - The remains } \\
\text { fetus showed } \\
\text { ossification, but } \\
\text { it is clear that } \\
\text { the long bones } \\
\text { shorten with no } \\
\text { fractures. } \\
\text { - The length of } \\
\text { femora } 6 \mathrm{~mm} \text {, } \\
\text { whereas the } \\
\text { humeri } 7 \mathrm{~mm} \text {, } \\
\text { with } \\
\text { metaphyseal } \\
\text { cupping of both } \\
\text { femora and } \\
\text { humeri was } \\
\text { seen. } \\
\text { - No ossification } \\
\text { of the vertebral } \\
\text { body showed by } \\
\text { photograph and } \\
\text { radiograph. }\end{array}$ & $\begin{array}{l}\text { - Disordered physis with } \\
\text { advanced periosteal } \\
\text { ossification, chondroid } \\
\text { deficient matrix, enlarged } \\
\text { chondrocyte lacunae, and } \\
\text { increased cartilage } \\
\text { vascularity with } \\
\text { perivascular fibrosis. } \\
\text { - The lack of vertebral body } \\
\text { ossification, but skull } \\
\text { ossification was present } \\
\text { and also rib ossification } \\
\text { was present without } \\
\text { fractures. } \\
\text { - No chondrocyte inclusions } \\
\text { - Disrupted markedly on the } \\
\text { pelvic bones, while the } \\
\text { hands showed faint } \\
\text { ossification of all } \\
\text { phalanges. The distal } \\
\text { femoral epiphysis and } \\
\text { proximal tibial epiphysis } \\
\text { were not ossified. }\end{array}$ \\
\hline
\end{tabular}

$\mathrm{USG}=$ ultrasonography

Table 5. Guidelines for the diagnostic of achondrogenesis.

\begin{tabular}{|c|c|c|c|c|c|c|c|}
\hline $\begin{array}{l}\text { Part of } \\
\text { skeleton }\end{array}$ & $\begin{array}{l}\text { Extremely short } \\
\text { femora and humeri } \\
\text { with }\end{array}$ & \multicolumn{2}{|c|}{$\begin{array}{l}\text { Additional skeleton } \\
\text { features }\end{array}$} & $\begin{array}{l}\text { Suggested } \\
\text { diagnosis }\end{array}$ & $\begin{array}{l}\text { Key histologic } \\
\text { findings in long } \\
\text { bones }\end{array}$ & $\begin{array}{l}\text { Mode of } \\
\text { inheritance }\end{array}$ & $\begin{array}{l}\text { Genetic } \\
\text { mutation }\end{array}$ \\
\hline \multirow[t]{2}{*}{$\begin{array}{l}\text { Long } \\
\text { bones }\end{array}$} & $\begin{array}{l}\text { Pattern: } \\
\text { Metaphyseal cupping } \\
\text { also look for: } \\
\text { unossified, small or } \\
\text { oval vertebral bodies }\end{array}$ & - & & ACG-2 & $\begin{array}{l}\text { - Physis abnormal } \\
\text {-Markedly enlarged } \\
\text { chondrocyte lacunae }\end{array}$ & $\begin{array}{l}\text { Autosome } \\
\text { dominant }\end{array}$ & COL2A1 \\
\hline & $\begin{array}{l}\text { Pattern: } \\
\text { None of the above } \\
\text { specific long bone } \\
\text { findings }\end{array}$ & $\begin{array}{l}\text { Vertebral } \\
\text { bodies: } \\
\text { unossified } \\
\text { or } \\
\text { small and } \\
\text { oval }\end{array}$ & $\begin{array}{l}\text { Skullpoorly } \\
\text { ossified }\end{array}$ & ACG-1B & $\begin{array}{l}\text { - Physis abnormal } \\
\text { - PAS + } \\
\text { chondrocyte } \\
\text { inclusions } \\
\text {-Physis abnormal } \\
\text {-Perichondrocyte } \\
\text { collagen rings }\end{array}$ & $\begin{array}{l}\text { Autosome } \\
\text { reccesive }\end{array}$ & SLC26A2 \\
\hline
\end{tabular}

\section{CONCLUSION}

Base on the fact of many case report we concluded that gen mutation caused abnormality in protein and cell metabolism. Abnormality in protein and cell metabolism than caused many organs disorders form, characterized with bones and cartilage malformation, and finally caused of congenital chondrodysplasia. Currently 3 type of ACG, such as ACG-1A, ACG-1B and ACG-2. ACG-1A caused by TRIP11 gen mutation, while ACG1B caused by diastrophic dysplasia sulfate transporter or DTDST (SLC26A2) gen mutation, whereas ACG-2 caused type 2 collagen (COL2A1) gen mutation. ACG-1A had characterized such as physis abnormal, vertebral bodies with unossified or small and oval, skull poorly ossified, chondrocyte inclusions finding in long bones. ACG-1B had physis abnormal, vertebral bodies with unossified or small and oval, skull ossified, perichondrocyte collagen 
rings finding in long bones. ACG-2 also had physis abnormal, metaphyseal cupping, vertebral bodies with unossified or small and oval, enlarged chondrocyte lacunae.

\section{Funding: No funding sources}

Conflict of interest: None declared

Ethical approval: Not required

\section{REFERENCES}

1. Smits P, Bolton AD, Funari V, Hong M, Boyden ED, $\mathrm{Lu} \mathrm{L}$ et al. Lethal skeletal dysplasia in mice and humans lacking the Golgin GMAP-210. N Engl J Med. 2010;362(2):206-16.

2. Shree RTR, Saraswathi K. A case report of antenatal diagnosis of achondrogenesis type I. Res J Pharmaceut Biol Chem Sci. 2015;6(6):551-5.

3. Camera G, Mastroiacovo P. Birth prevalence os skeletal dysplasias in the İtalian multicentric monitoring system for birth defects. Proq Clin Biol Res. 1982;101:441-9.

4. Borochowitz Z, Lachman R, Adornian GE, Spear G, Jones K, Rimoin DL. Achondrogenesis type I: delineation of further heterogeneity and identification of two distinct subgroups. J Pediatr. 1988;112:23-31.

5. van der Harten HJ, Brons JTJ, Dijkstra PF, Niermeyer MF, Meijer CJ, van Giejn HP, et al. Achondrogenesis-hypochondrogenesis: the spectrum of chondrogenesis imperfecta. Pediatr Pathol. 1988;8:571-97.

6. Urso FP, Urso MJ. Achondrogenesis in two sibs. Birth Defects. 1974;10:10-17.

7. Nardi F, Gerlini G, Bonucci E. Achondrogenesis: report on a case, with particular reference to ultrastructure and histochemistry. Virchows Arch A Pathol Anat Histol. 1974;363:311-22.

8. Molz G, Spycher MA. Achondrogenesis type I: light and electron-microscopic study. Eur J Pediatr. 1980;134:69-74.

9. Parenti GC. La anosteogenesi. Pathologica (Genova) 1936;28:447-62.

10. Weisman PS, Kashireddy PV, Ernst LM. Pathologic diagnosis of achondrogenesis type 2 in a fragmented fetus: case report and evidence-based differential diagnostic approach in the early midtrimester. Ped Dev Pathol. 2014;17:10-20.

11. Chen H. Achondrogenesis. Drugs and Diseases. 2013. Jun 26, Available at http://emedicine.staging.medscape.com/article/94117 6-overview

12. Whitley CB, Gorlin RJ. Achondrogenesis: new nosology with evidence of genetic heterogeneity. Radiol. 1983;148:693-8.

13. Superti-Furga A. Achondrogenesis type 1B. J Med Genet. 1996;33:957-61.

14. Segal NL, Feng R, McGuire SA, Allison DB, Miller S. Genetic and environmental contributions to body mass index: comparative analysis of monozygotic twins, dizygotic twins and same-age unrelated siblings. Int J Obes (Lond). 2009;33(1):37-41.

15. Parwanto ME, Senjaya H. Dietary intake of mother in childbearing age with BMI $<18.5 \mathrm{~kg} / \mathrm{m}^{2}$ and has heterozygous variant D327N SHBG genotype (w/v). Int J Community Med Public Health. 2017;4:409-17.

16. Infante $\mathrm{C}$, Ramos-Morales $\mathrm{F}$, Fedriani $\mathrm{C}$, Bornens $\mathrm{M}$, and Rios RM. GMAP-210, A cis-Golgi networkassociated protein, is a minus end microtubulebinding protein. J Cell Biol. 1999;145(1):83-98.

17. Follit JA, San Agustin JT, Xu F, Jonassen JA, Samtani R et al. The Golgin GMAP210/TRIP11 Anchors IFT20 to the Golgi Complex. PLoS Genet. 2008;4(12):e1000315.

18. Wilson C, Venditti R, Rega LR, Colanzi A, d'Angelo G, de Matteis A. The Golgi apparatus: an organelle with multiple complex functions. Biochem J. 2011;433:1-9.

19. Haila S, Hästbacka J, Böhling T, KarjalainenLindsberg ML, Kere J, Saarialho-Kere U. SLC26A2 (diastrophic dysplasia sulfate transporter) is expressed in developing and mature cartilage but also in other tissues and cell types. J Histochem Cytochem. 2001;49(8):973-82.

20. Vissing H, D'Alessio M, Lee B, Ramirez F, Godfrey M, Hollister DW. Glycine to serine substitution in the triple helical domain of pro-alpha 1 (II) collagen results in a lethal perinatal form of shortlimbed dwarfism. J Biol Chem. 1989;264:18265-7.

21. Mortier GR, Weis MA, Nuytinck L, King LM, Wilkin DJ, Paepe AD et al. Report of five novel and one recurrent COL2A1 mutations with analysis of genotype-phenotype correlation in patients with a lethal type II collagen disorder. J Med Genet. 2000;37:263-271.

22. Nikkels PG. Diagnostic approach to congenital osteochondrodysplasias at autopsy. Diagn Histopathol. 2009;15:413-58.

23. Gilbert-Barness E. Osteochondrodysplasias: constitutional diseases of bone. In: Gilbert-Barness E, ed. Potter's Pathology of the Fetus, Infant, and Child. 2nd ed. Philadelphia: Mosby Elsevier;2007:1836-97.

24. Taner MZ, Kurdoglu M, Taskiran C, Onan MA, Gunaydin G, Himmetoglu O. Prenatal diagnosis of achondrogenesis type I: a case report. Cases J. 2008; 1:406.

25. Tunc SY, Demir V, Agacayak E, Icen MS, Findik FM and Yildizbakan A. A Rare Skeletal Dysplasia: Achondrogenesis Type 1. IJBCS. 2015;4(1):66-70.

26. Aigner T, Rau T, Niederhagen M, Zaucke F, Schmitz M, Pöhls U et al. Achondrogenesis Type IA (Houston-Harris): a still-unresolved molecular phenotype. Pediatr Dev Pathol. 2007;10:328-34.

27. Lee HS, Doh JW, Kim CJ, Chi JG. Achondrogenesis type II (Langer-Saldino Achondrogenesis): A case report. J Korean Med Sci. 2000;15:604-8.

28. Forzano F, Lituania M, Viassolo V, Superti-Furga A, Wildhardt G, Zabel B et al. A familial case of achondrogenesis type II caused by a dominant 
COL2A1 mutation and "patchy" expression in the mosaic father. Am J of Med Gen Part A. 2007;143A:2815-20.

29. Hansen K, Sung CJ, Huang C, Pinar H, Singer DB, Oyer CE. Reference values for second trimester fetal and neonatal organ weights and measurements. Pediatr Dev Pathol. 2003;6:160-7.

30. Elejalde BR, de Elejalde MM. The prenatal growth of the human body determined by the measurement of bones and organs by ultrasonography. Am J Med Genet. 1986;24:575-98.

Cite this article as: Parwanto MLE. The genetic aspect and morphological appearance of achondrogenesis. Int J Reprod Contracept Obstet Gynecol 2017;6:3203-12. 